\title{
Article
}

\section{Assessment and Clinical Utility of a Non-Next-Generation Sequencing-Based Non-Invasive Prenatal Testing Technology}

\author{
Uzay Gormus ${ }^{1}$, Alka Chaubey ${ }^{2,3}{ }^{\circ}$, Suresh Shenoy ${ }^{2}$, Yong Wee Wong ${ }^{4}$, Lee Yin Chan ${ }^{4}$, Bao Ping Choo ${ }^{4}$, \\ Liza Oraha ${ }^{1}$, Anna Gousseva ${ }^{5}$, Fredrik Persson ${ }^{5}$, Lawrence Prensky ${ }^{6, *} \mathbb{E}$, Ephrem Chin ${ }^{2}$ and Madhuri Hegde ${ }^{2}$ \\ 1 PerkinElmer Genomics Sweden, 19138 Sollentuna, Sweden; Uzay.Gormus@PERKINELMER.COM (U.G.); \\ Liza.Oraha@PERKINELMER.COM (L.O.) \\ 2 PerkinElmer Genomics, Pittsburgh, PA 15275, USA; achaubey@bionanogenomics.com (A.C.); \\ Suresh.Shenoy@PERKINELMER.COM (S.S.); Ephrem.Chin@PERKINELMER.COM (E.C.); \\ Madhuri.Hegde@PERKINELMER.COM (M.H.) \\ 3 Bionano Genomics, San Diego, CA 92121, USA \\ 4 DNA Laboratories Sdn. Bhd, PerkinElmer Genomics Malaysia, Bangi 43650, Selangor, Malaysia; \\ YongWee.Wong@PERKINELMER.COM (Y.W.W.); LeeYin.Chan@PERKINELMER.COM (L.Y.C.); \\ BaoPing.Choo@PERKINELMER.COM (B.P.C.) \\ 5 Vanadis Diagnostics, PerkinElmer Inc., 19138 Sollentuna, Sweden; \\ Anna.Gousseva@PERKINELMER.COM (A.G.); Fredrik.Persson@PERKINELMER.COM (F.P.) \\ 6 PerkinElmer Inc., Waltham, MA 02451, USA \\ check for \\ updates \\ * Correspondence: Lawrence.Prensky@Perkinelmer.com
}

Citation: Gormus, U.; Chaubey, A. Shenoy, S.; Wong, Y.W.; Chan, L.Y.; Choo, B.P.; Oraha, L.; Gousseva, A.; Persson, F.; Prensky, L.; et al. Assessment and Clinical Utility of a Non-Next-Generation

Sequencing-Based Non-Invasive Prenatal Testing Technology. Curr. Issues Mol. Biol. 2021, 43, 958-964. https://doi.org/10.3390/ cimb43020068

Academic Editor: Arumugam R. Jayakumar

Received: 29 June 2021

Accepted: 13 August 2021

Published: 17 August 2021

Publisher's Note: MDPI stays neutral with regard to jurisdictional claims in published maps and institutional affiliations.

Copyright: () 2021 by the authors. Licensee MDPI, Basel, Switzerland. This article is an open access article distributed under the terms and conditions of the Creative Commons Attribution (CC BY) license (https:// creativecommons.org/licenses/by/ $4.0 /)$.

\begin{abstract}
Background: Rolling-circle replication (RCR) is a novel technology that has not been applied to cell-free DNA (cfDNA) testing until recently. Given the cost and simplicity advantages of this technology compared to other platforms currently used in cfDNA analysis, an assessment of RCR in clinical laboratories was performed. Here, we present the first validation study from clinical laboratories utilizing RCR technology. Methods: 831 samples from spontaneously pregnant women carrying a singleton fetus, and 25 synthetic samples, were analyzed for the fetal risk of trisomy 21 (T21), trisomy 18 (T18) and trisomy 13 (T13), by three laboratories on three continents. All the screenpositive pregnancies were provided post-test genetic counseling and confirmatory diagnostic invasive testing (e.g., amniocentesis). The screen-negative pregnancies were routinely evaluated at birth for fetal aneuploidies, using newborn examinations, and any suspected aneuploidies would have been offered diagnostic testing or confirmed with karyotyping. Results: The study found rolling-circle replication to be a highly viable technology for the clinical assessment of fetal aneuploidies, with 100\% sensitivity for T21 (95\% CI: 82.35-100.00\%); 100.00\% sensitivity for T18 (71.51-100.00\%); and $100.00 \%$ sensitivity for T13 analyses (66.37-100.00\%). The specificities were $>99 \%$ for each trisomy (99.7\% (99.01-99.97\%) for T21; 99.5\% (98.62-99.85\%) for T18; 99.7\% (99.03-99.97\%) for T13), along with a first-pass no-call rate of $0.93 \%$. Conclusions: The study showed that using a rolling-circle replication-based cfDNA system for the evaluation of the common aneuploidies would provide greater accuracy and clinical utility compared to conventional biochemical screening, and it would provide comparable results to other reported cfDNA methodologies.
\end{abstract}

Keywords: cell-free DNA; noninvasive prenatal screening; noninvasive prenatal testing; NIPT; NIPS; validation study; rolling-circle replication; digital quantification; prenatal screening; aneuploidy

\section{Introduction}

Trisomies are important chromosomal aberrations that are often associated with varying degrees of intellectual disabilities, several health and developmental defects, and whose incidence is correlated with increasing maternal age [1]. Although the average maternal age has increased globally in the last 50 years, the incidence of trisomy has significantly decreased during that time frame due to the increased utilization of improved prenatal screening tests [2]. Historically, these prenatal screening tests consisted of biochemical 
blood tests and/or ultrasound scans. These conventional screening tests are still used globally, but due to their higher false positive rates and lower detection rates, they have started to be replaced by newer, more accurate technologies using the placental cell-free DNA (cfDNA) circulating in the maternal blood. Cell-free nucleic acids, also known as extracellular nucleic acids, are fragments of DNA or RNA molecules that are released from cells into the body fluids.

Lo et al. were the first to report that a portion of the cell-free DNA in maternal blood was from the fetus and placenta, and to comment on how cell-free fetal DNA was suitable for prenatal examinations [3]. The introduction of cell-free DNA into prenatal clinical practice first started through the use of next-generation sequencing (NGS) technology, for the assessment of trisomy 21 (T21), trisomy 18 (T18), and trisomy 13 (T13), and was referred to as noninvasive prenatal testing (NIPT) $[4,5]$. Although NIPT has been shown to be highly accurate, the next-generation sequencing techniques that were used has limited the global accessibility to this test due to its high cost and complexity. It has been noted that a considerable cost reduction is necessary to make this approach cost effective enough to be commonly used [6]. Furthermore, the complexity of the NGS-based technologies adds additional hurdles to the ability of laboratories to implement this test. Vanadis ${ }^{\circledR}$ NIPT was developed without using NGS or polymerase chain reaction (PCR), to enable a cost effective and high-performance cfDNA aneuploidy screening.

Vanadis ${ }^{\circledR}$ NIPT is a new technology targeting relevant chromosomes, based on digital molecular quantification in a 96-well microplate $[7,8]$. The method converts targeted chromosomal fragments into digitally quantifiable objects through rolling-circle replication and chromosome-specific labeling. The normalized ratio between the number of chromosome-specific objects is then used to calculate the z-score, which is mapped to a post-test risk.

Here, we report the clinical performance of the Vanadis ${ }^{\circledR}$ NIPT assay in PerkinElmer Genomics Laboratories.

\section{Materials and Methods}

\subsection{Ethics Statement}

Protocols used for sample collection were approved by the Research Ethics Board of CHU de Québec (\#2016-2989 on 13 April 2016 and \#2020-4895 on 23 September 2019). The study was performed in accordance with the ethical standards of the institutional and/or national research committees.

\subsection{Study Population and Clinical Evaluation}

Validation protocols were written based upon templates relevant to the Vanadis system (Supplementary Materials A and B). Based on this, a total aggregated set of 831 samples from spontaneously pregnant women carrying a singleton fetus were analyzed. The inclusion criteria for participation in this study were pregnant women between the ages of 18 and 50 and between 10 and 40 gestational weeks. The women were not selected based on prior risk and all consented to participate in the study. All screen-positive pregnancies were provided post-test genetic counseling and confirmatory diagnostic invasive testing (e.g., amniocentesis). Screen-negative pregnancies were routinely evaluated at birth for fetal aneuploidies using newborn examinations and any suspected aneuploidies would have been offered diagnostic testing or confirmed with karyotyping. Ten milliliters $(\mathrm{mL})$ of blood were collected from each woman between February 2019 and July 2019 at maternity clinics in Kuala Lumpur and Quebec. Blood samples were processed as described below, and at least $3 \mathrm{~mL}$ of plasma was extracted and sent to PerkinElmer Genomics (PKIG) labs located in Sollentuna, Sweden; Kuala Lumpur, Malaysia; and Pittsburgh, PA, USA.

Ten samples from confirmed T21-positive pregnancies, three samples from confirmed T18-positive pregnancies, and one sample from a confirmed T13 pregnancy were used. Other trisomy-positive control samples (nine of T21, eight of T18 and eight of T13) were purchased from SeraCare Life Sciences, Inc. (Milford, MA, USA) (Seraseq trisomy 
21 aneuploidy reference material-0720-0019, trisomy 13 aneuploidy reference material0720-0017, trisomy 18 aneuploidy reference material-0720-0018).

\subsection{Sample Collection and Preparation}

Blood samples were collected into cell-free TM DNA BCT tubes (Streck, Omaha, NE, USA) from each pregnant woman. After arrival in the lab by courier, study samples were barcoded with unique subject codes and patient identification numbers and anonymized.

Samples were processed in the PKIG lab in Kuala Lumpur and the CHU de QuébecUniversité Laval lab in Quebec by using a double-centrifugation protocol [8]. All plasma was separated within 5 days of blood draw and stored in new plasma storage tubes. The plasma tubes were barcoded with unique subject codes and patient identification numbers were anonymized. The plasma tubes were stored at $-80^{\circ} \mathrm{C}$ until processing at a PKIG Laboratory.

\subsection{Test Method}

Samples were analyzed using the Vanadis ${ }^{\circledR}$ system (PerkinElmer Inc., Sollentuna, Sweden) following existing manuals and instructions for use. The Vanadis ${ }^{\circledR}$ NIPT assay uses a series of enzymatic steps to generate labelled rolling-circle replication products (RCPs) from chromosomal cfDNA targets, as previously described [7]. Automated extraction of cfDNA from plasma was performed using the Vanadis Extract ${ }^{\circledR}$ platform, followed by continued processing on the Vanadis Core ${ }^{\circledR}$ platform to generate labelled RCPs, which were then imaged and counted using the Vanadis View ${ }^{\circledR}$ instrument. The performance metrics to be evaluated were based on the Z-score results that were calculated with Lifecycle ${ }^{\mathrm{TM}}$ software version 7.2 (PerkinElmer Inc., Turku, Finland) and exported to an Excel file.

\subsection{Data Analysis and Sample Classification}

Automated data analysis and quality assessment were performed, and chromosomal ratio calculations were calculated for all approved samples. The results were classified into low or high risk with a Z-score approach based on each normalized chromosomal ratio and the sample-specific standard deviation. The Z-score cut-off values were 3.5 for chromosome 21, and 3.15 for chromosomes 18 and 13. The samples that failed the quality assessment were rejected and classified as 'no-call'. The fetal sex was classified from the number of detected RCPs from chromosome $\mathrm{Y}$ relative to the number of RCPs from the measured autosomal chromosomes using an adaptive binary classifier $[7,8]$. Measured fetal fraction, which is often thought to be a useful quality control metric, was not gathered as recent studies have shown that it can be significantly incorrect [9].

\section{Results}

A total of 856 samples (Table 1) were included in the study, 831 of them were taken from singleton pregnancies with spontaneous fertilization, and 25 were reference material provided by SeraCare Life Sciences, Inc. (Milford, MA, USA). There were eight first-pass no-call results that were excluded from the calculations (first-pass no-call rate: $0.93 \%$ ). The average median maternal age in the study group was 32 (min: 20 years, max: 46 years). The median gestational age was 12 weeks and 5 days (min: 10 weeks, max: 34 weeks).

The results from the test (Table 2) showed 100\% sensitivity for T21 (95\% confidence interval (CI): $82.35-100.00 \%$ ); $100.00 \%$ sensitivity for T18 (95\% CI: $71.51-100.00 \%$ ); and $100.00 \%$ sensitivity for T13 analyses (95\% CI: 66.37-100.00\%). The specificities were $>99 \%$ for each trisomy (99.7\% (95\% CI: 99.01-99.97\%) for T21; 99.5\% (95\% CI: 98.62-99.85\%) for T18; 99.7\% (95\% CI: 99.03-99.97\%) for T13).

No false negative results were detected (FNR: $0 \%$ ), with low levels of false positive rates (FPR: $0.24 \%$ for T21, $0.47 \%$ for T18, and $0.24 \%$ for T13). For fetal gender assessment, the accuracy was $98.80 \%$ (Table 3 ). 
Table 1. Characteristics of study subjects.

\begin{tabular}{cc}
\hline Characteristic & Values \\
\hline Euploid subjects & 817 \\
\hline T21 samples & 19 (10 pregnant samples, 9 reference materials $)$ \\
\hline T18 samples & 11 (3 pregnant sample, 8 reference materials $)$ \\
\hline T13 samples & 9 (1 pregnant sample, 8 reference materials $)$ \\
\hline Maternal age, median (min-max) & 32 (20 years-46 years) \\
\hline Gestational age, median (min-max) & 12 weeks 5 days (10 weeks-34 weeks) \\
\hline First pass no calls & 8 \\
\hline
\end{tabular}

Table 2. Test performance Vanadis ${ }^{\circledR}$ NIPT-Aneuploidy (Sweden + Malaysia + USA).

\begin{tabular}{cccc}
\hline$\cdot$ & Trisomy 21 & Trisomy 18 & Trisomy 13 \\
\hline Total subjects & $408+214+234=856$ & $408+214+234=856$ & $408+214+234=856$ \\
\hline No calls: & \multicolumn{2}{c}{8 (no call rate: $0.93 \%$, with unrepeated samples) } \\
\hline Without no calls: & 848 & 848 & 848 \\
\hline True positives + & $7(5)+4(0)+8(4)=19$ & $7(6)+2(0)+2(2)=11$ & $6(6)+1(0)+2(2)=9$ \\
\hline False positives & $2+0+0=2$ & $4+0+0=4$ & $1+0+1=2$ \\
\hline True negatives & 827 & 833 & 837 \\
\hline False negatives & 0 & 0 & 0 \\
\hline Sensitivity (95\% CI) & $100.00 \%(82.35 \%$ to $100.00 \%)$ & $100.00 \%(71.51 \%$ to $100.00 \%)$ & $100.00 \%(66.37 \%$ to $100.00 \%)$ \\
\hline Specificity $(95 \% \mathrm{CI})$ & $99.76 \%(99.13 \%$ to $99.97 \%)$ & $99.52 \%(98.78 \%$ to $99.87 \%)$ & $99.76 \%(99.14 \%$ to $99.97 \%)$ \\
\hline
\end{tabular}

† 25 out of 39 are SeraCare samples; SeraCare samples are within parentheses.

Table 3. Test performance Vanadis ${ }^{\circledR}$ NIPT—sex classification.

\begin{tabular}{|c|c|c|c|c|c|c|c|c|}
\hline \multicolumn{3}{|c|}{ Sweden } & \multicolumn{3}{|c|}{ Malaysia } & \multicolumn{3}{|c|}{ USA } \\
\hline \multicolumn{3}{|c|}{391} & \multicolumn{3}{|c|}{214} & \multicolumn{3}{|c|}{234} \\
\hline & Females & Males & & Females & Males & & Females & Males \\
\hline Total subjects & 166 & 225 & Total subjects & 94 & 120 & Total subjects & 101 & 133 \\
\hline No calls & \multicolumn{2}{|c|}{6} & No calls & \multicolumn{2}{|c|}{2} & No calls & \multicolumn{2}{|c|}{0} \\
\hline $\begin{array}{c}\text { Total subjects (w/o } \\
\text { no calls) }\end{array}$ & 164 & 221 & $\begin{array}{c}\text { Total subjects (w/o } \\
\text { no calls) }\end{array}$ & 92 & 120 & $\begin{array}{l}\text { Total subjects (w/o } \\
\text { no calls) }\end{array}$ & 101 & 133 \\
\hline $\begin{array}{c}\text { Correct } \\
\text { classification }\end{array}$ & 162 & 220 & $\begin{array}{c}\text { Correct } \\
\text { classification }\end{array}$ & 92 & 120 & $\begin{array}{c}\text { Correct } \\
\text { classification }\end{array}$ & 98 & 129 \\
\hline \multirow[t]{2}{*}{$\begin{array}{c}\text { Incorrect } \\
\text { classification }\end{array}$} & 2 & 1 & $\begin{array}{c}\text { Incorrect } \\
\text { classification }\end{array}$ & 0 & 0 & $\begin{array}{c}\text { Incorrect } \\
\text { classification }\end{array}$ & 3 & 4 \\
\hline & Females & Males & TOTAL & $\begin{array}{l}\text { Performa } \\
\text { Criteria }\end{array}$ & Females & Males & \multicolumn{2}{|c|}{ TOTAL } \\
\hline Total subjects & 361 & 478 & 839 & Accuracy & $98.79 \%$ & $98.79 \%$ & \multicolumn{2}{|c|}{$98.79 \%$} \\
\hline No calls excluded: & 357 & 474 & 831 & & & & & \\
\hline $\begin{array}{c}\text { Correct } \\
\text { classification }\end{array}$ & 352 & 469 & 821 & & & & & \\
\hline $\begin{array}{c}\text { Incorrect } \\
\text { classification }\end{array}$ & 5 & 5 & 10 & & & & & \\
\hline
\end{tabular}

\section{Discussion}

Vanadis ${ }^{\circledR}$ NIPT is an efficient and cost-effective option for prenatal screening. The test can be offered to pregnant women starting from the 10th week of gestation and can be integrated as a first tier choice as prenatal screening analysis, as it is more cost-effective than the NGS-based NIPT [10] and has a higher sensitivity and specificity compared to the conventional biochemical screening [11].

This study shows the high sensitivity and specificity of Vanadis NIPT analysis. In this sample set, all the aneuploidy cases were detected accurately, thus resulting in a sensitivity of $100 \%$ for trisomy 21 , trisomy 18 , and trisomy 13 , and a $\geq 99.5 \%$ specificity. The specificity 
would likely be even higher if a second tube of blood was available for the samples with borderline Z-scores. Furthermore, if a second sample was available for these patients, then the low first-pass no-call rate of $0.93 \%$ would likely be reduced to a final no-call rate of around $0.1 \%$, based upon a previous study showing a $87.5 \%$ reduction of no calls when a second sample is run on the Vanadis ${ }^{\circledR}$ system [12].

Studies have shown that the sensitivity and specificity of NIPT are better than the conventional screening methods [13-21], which has led professional societies (such as the American College of Obstetricians and Gynecologists, and the Society for Maternal-Fetal Medicine) to state "Cell-free DNA is the most sensitive and specific screening test for the common fetal aneuploidies" [11]. NIPT technologies that involve next-generation sequencing have shown that $98-100 \%$ of common aneuploidies can be detected at a combined false positive rate of $0.44-0.91 \%$ [22], while conventional biochemical screening can range from 50 to $95 \%$, with a false positive rate of $5 \%$, depending upon which screening strategy is used [23]. By providing higher detection rates and lower false positive and negative rates compared to conventional screening, NIPT technologies are more clinically effective and lead to fewer invasive procedures [24].

As this study shows, the Vanadis ${ }^{\circledR}$ system provided results that are comparable to those of the more common NIPT technologies (Table 4). Both groups show similar sensitivities and specificities, which are greater than those for the conventional biochemical screening, thus emphasizing their clinical utility. Although similar in performance, there is a difference when it comes to the technological complexity and cost effectiveness. By removing the need for PCR and NGS, the installation, hands-on time, bioinformatics, and run costs, are automatically significantly lower with the Vanadis system. As has been reported, there is additionally a cost saving for medical systems using this technology over sequencing from a follow-up point of view, due to the lower no-call rate [10].

Irrespective of the technology or methodology, there are some limitations to NIPT analysis which help to explain the discrepancies between the test results and the fetal status. For example, since the cell-free fetal DNA is mainly produced by the placenta rather than the fetus, false positive results can arise due to placental mosaicism [25-27] or the presence of a vanishing twin $[28,29]$. Additionally, false positive results or no-call results may appear as a result of maternal cancer [30] or maternal chromosome anomalies [31]. Other limitations of the assay could arise from complex chromosomal abnormalities [26,32,33].

Table 4. Comparison of next-generation sequencing NIPT vs. Vanadis ${ }^{\circledR}$ NIPT.

\begin{tabular}{ccc}
\hline & NGS NIPT [5,15,22,34-36] & Vanadis [8] * \\
\hline No call results & $0.7-6.6 \%$ & $0.1-0.9 \%$ \\
\hline Sensitivity (21) & $98.6->99.9 \%$ & $>99.9 \%$ \\
\hline Sensitivity (18) & $90->99.9 \%$ & $89->99.9 \%$ \\
\hline Sensitivity (13) & $91.7->99.9 \%$ & $>99.9 \%$ \\
\hline Specificity (21) & $99.5-99.9 \%$ & $99.8->99.9 \%$ \\
\hline Specificity (18) & $99.7->99.9 \%$ & $99.5 \%$ \\
\hline Specificity (13) & $99.0-99.8 \%$ & $99.8->99.9 \%$ \\
\hline${ }^{*}$ Including this study. & &
\end{tabular}

This study illustrates the high accuracy and clinical utility of Vanadis ${ }^{\circledR}$ NIPT compared to traditional prenatal screening methods for common aneuploidy. As an equally accurate and reliable NIPT test, Vanadis ${ }^{\circledR}$ NIPT can help eliminate the barrier to the widespread usage of prenatal cfDNA for the global pregnancy population by being a technology that is significantly less complex to run and more cost effective.

Supplementary Materials: The following are available online at https:/ / www.mdpi.com/article/10 $.3390 /$ cimb43020068/s1.

Author Contributions: Conceptualization, A.C. and F.P.; methodology, F.P., Y.W.W. and L.Y.C.; validation, A.C., U.G., S.S., L.Y.C., L.O. and Y.W.W.; formal analysis, A.C., U.G., S.S., L.Y.C. and Y.W.W.; investigation, A.G., U.G., S.S., L.Y.C., B.P.C., Y.W.W. and L.O.; resources, E.C.; writing- 
original draft preparation, U.G. and L.P.; writing-review and editing, A.C., F.P., S.S. and Y.W.W.; supervision, E.C. and M.H.; project administration, E.C.; funding acquisition, E.C. All authors have read and agreed to the published version of the manuscript.

Funding: This research received no external funding.

Institutional Review Board Statement: The study was conducted according to the guidelines of the Declaration of Helsinki, and approved by the Research Ethics Board of CHU de Québec (\#2016-2989 and \#2020-4895) (13 April 2016 and 20 September 2019).

Data Availability Statement: The data presented in this study are available on request from the corresponding author. The data are not publicly available due to privacy concerns.

Acknowledgments: The authors would like to thank Emmanuel Bujold and members of the Perinatal Biobank of the CHU de Québec-Université Laval for their assistance in collecting and preparing samples.

Conflicts of Interest: All authors are current or former employees of PerkinElmer Inc. (Waltham MA, USA).

\section{References}

1. Carothers, A.D.; Hecht, C.A.; Hook, E. International variation in reported livebirth prevalence rates of Down syndrome, adjusted for maternal age. J. Med. Genet. 1999, 36, 386-393.

2. Huete-García, A.; Otaola-Barranquero, M. Demographic Assessment of Down Syndrome: A Systematic Review. Int. J. Environ. Res. Public Health 2021, 18, 352. [CrossRef] [PubMed]

3. Lo, Y.M.; Corbetta, N.; Chamberlain, P.F.; Rai, V.; Sargent, I.L.; Redman, C.W.; Wainscoat, J.S. Presence of fetal DNA in maternal plasma and serum. Lancet 1997, 350, 485-487. [CrossRef]

4. Dondorp, W.; de Wert, G.; Bombard, Y.; Bianchi, D.; Bergmann, C.; Borry, P.; Chitty, L.; Fellmann, F.; Forzano, F.; Hall, A.; et al. Non-invasive prenatal testing for aneuploidy and beyond: Challenges of responsible innovation in prenatal screening. Eur. J. Hum. Genet. 2015, 23, 1592, Erratum in 2015, 23, 1438-1450. [CrossRef]

5. Gil, M.M.; Accurti, V.; Santacruz, B.; Plana, M.N.; Nicolaides, K.H. Analysis of cell-free DNA in maternal blood in screening for aneuploidies: Updated meta-analysis. Ultrasound Obstet. Gynecol. 2017, 50, 302-314, Update in 2019, 53, 734-742. [CrossRef] [PubMed]

6. Ayres, A.C.; Whitty, J.A.; Ellwood, D.A. A cost-effectiveness analysis comparing different strategies to implement noninvasive prenatal testing into a Down syndrome screening program. Aust. N. Z. J. Obstet. Gynaecol. 2014, 54, 412-417. [CrossRef]

7. Dahl, F.; Ericsson, O.; Karlberg, O.; Karlsson, F.; Howell, M.; Persson, F.; Roos, F.; Stenberg, J.; Ahola, T.; Alftren, I.; et al. Imaging single DNA molecules for high precision NIPT. Sci. Rep. 2018, 8, 4549. [CrossRef]

8. Ericsson, O.; Ahola, T.; Dahl, F.; Karlsson, F.; Persson, F.; Karlberg, O.; Roos, F.; Alftren, I.; Andersson, B.; Barkenas, E.; et al. Clinical validation of a novel automated cell-free DNA screening assay for trisomies 21, 13, and 18 in maternal plasma. Prenat. Diagn. 2019, 39, 1011-1015. [CrossRef]

9. Persson, F.; Prensky, L. Variability of "Reported Fetal Fraction" in Noninvasive Prenatal Screening (NIPS). Clin. Chem. 2021, 67, 863-866. [CrossRef]

10. Huang, T.; Gibbons, C.; Rashid, S.; Priston, M.K.; Bedford, H.M.; Mak-Tam, E.; Meschino, W.S. Prenatal screening for trisomy 21: A comparative performance and cost analysis of different screening strategies. BMC Pregnancy Childbirth 2020, 20, 713. [CrossRef]

11. American College of Obstetricians and Gynecologists' Committee on Practice Bulletins_Obstetrics; Committee on Genetics; Society for Maternal-Fetal Medicine. Screening for Fetal Chromosomal Abnormalities: ACOG Practice Bulletin, Number 226. Obstet. Gynecol. 2020, 136, e48-e69. [CrossRef] [PubMed]

12. Karlsson, F.; Ahola, T.; Dahlberg, J.; Prensky, L.; Moilanen, H.; Spalding, H. Evaluation of repeat testing of a non-sequencing based NIPT test on a Finnish general-risk population. Acta Obstet. Gynecol. Scand. 2021, 11. [CrossRef]

13. Chiu, R.W.; Akolekar, R.; Zheng, Y.W.; Leung, T.Y.; Sun, H.; Chan, K.C.; Lun, F.M.; Go, A.T.; Lau, E.T.; To, W.W.; et al. Non-invasive prenatal assessment of trisomy 21 by multiplexed maternal plasma DNA sequencing: Large scale validity study. BMJ 2011, 342, c7401. [CrossRef] [PubMed]

14. Ehrich, M.; Deciu, C.; Zwiefelhofer, T.; Tynan, J.A.; Cagasan, L.; Tim, R.; Lu, V.; McCullough, R.; McCarthy, E.; Nygren, A.O.; et al. Noninvasive detection of fetal trisomy 21 by sequencing of DNA in maternal blood: A study in a clinical setting. Am. J. Obstet. Gynecol. 2011, 204, 205.e1-205.e11. [CrossRef] [PubMed]

15. Palomaki, G.E.; Kloza, E.M.; Lambert-Messerlian, G.M.; Haddow, J.E.; Neveux, L.M.; Ehrich, M.; van den Boom, D.; Bombard, A.T.; Deciu, C.; Grody, W.W.; et al. DNA sequencing of maternal plasma to detect Down syndrome: An international clinical validation study. Genet. Med. 2011, 13, 913-920. [CrossRef]

16. Sehnert, A.J.; Rhees, B.; Comstock, D.; de Feo, E.; Heilek, G.; Burke, J.; Rava, R.P. Optimal detection of fetal chromosomal abnormalities by massively parallel DNA sequencing of cell-free fetal DNA from maternal blood. Clin. Chem. 2011, 57, 1042-1049. [CrossRef] [PubMed] 
17. Sparks, A.B.; Struble, C.A.; Wang, E.T.; Song, K.; Oliphant, A. Non-invasive prenatal detection and selective analysis of cell-free DNA obtained from maternal blood: Evaluation for trisomy 21 and trisomy 18. Am. J. Obstet. Gynecol. 2012, 206, 319.e1-319.e9. [CrossRef]

18. Ashoor, G.; Syngelaki, A.; Wagner, M.; Birdir, C.; Nicholaides, K.H. Chromosome-selective sequencing of maternal plasma cell-free DNA for first-trimester detection of trisomy 21 and trisomy 18. Am. J. Obstet. Gynecol. 2012, 206, 322.e1-322.e5. [CrossRef]

19. Norton, M.E.; Brar, H.; Weiss, J.; Karimi, A.; Laurent, L.C.; Caughey, A.B.; Rodriguez, M.H.; Williams, J., 3rd; Mitchell, M.E.; Adair, C.D.; et al. Non-Invasive Chromosomal Evaluation (NICE) Study: Results of a multicenter prospective cohort study for detection of fetal trisomy 21 and trisomy 18. Am. J. Obstet. Gynecol. 2012, 207, 137.e1-137.e8. [CrossRef]

20. Bianchi, D.W.; Platt, L.D.; Goldberg, J.D.; Abuhamad, A.Z.; Sehnert, A.J.; Rava, R.P.; MatErnal BLood IS Source to Accurately diagnose fetal aneuploidy (MELISSA) Study Group. Genome-wide fetal aneuploidy detection by maternal plasma DNA sequencing. Obstet. Gynecol. 2012, 119, 890-901. [CrossRef]

21. Nicolaides, K.H.; Syngelaki, A.; Ashoor, G.; Birdir, C.; Touzet, G. Noninvasive prenatal testing for fetal trisomies in a routinely screened first-trimester population. Am. J. Obstet. Gynecol. 2012, 207, 374.e1-374.e6. [CrossRef] [PubMed]

22. Rousseau, F.; Langlois, S.; Johnson, J.A.; Gekas, J.; Bujold, E.; Audibert, F.; Walker, M.; Giroux, S.; Caron, A.; Clément, V.; et al. Prospective head-to-head comparison of accuracy of two sequencing platforms for screening for fetal aneuploidy by cell-free DNA: The PEGASUS study. Eur. J. Hum. Genet. 2019, 27, 1701-1715. [CrossRef] [PubMed]

23. Gregg, A.R.; Skotko, B.G.; Benkendorf, J.L.; Monaghan, K.G.; Bajaj, K.; Best, R.G.; Klugman, S.; Watson, M.S. Noninvasive prenatal screening for fetal aneuploidy, 2016 update: A position statement of the American College of Medical Genetics and Genomics. Genet. Med. 2016, 18, 1056-1065. [CrossRef]

24. Chetty, S.; Garabedian, M.J.; Norton, M.E. Uptake of noninvasive prenatal testing (NIPT) in women following positive aneuploidy screening. Prenat. Diagn. 2013, 33, 542-546. [CrossRef]

25. Srebniak, M.I.; Diderich, K.E.; Noomen, P.; Dijkman, A.; de Vries, F.A.T.; van Opstal, D. Abnormal non-invasive prenatal test results concordant with karyotype of cytotrophoblast but not reflecting abnormal fetal karyotype. Ultrasound Obstet. Gynecol. 2014, 44, 109-111. [CrossRef]

26. Grati, F.R.; Malvestiti, F.; Ferreira, J.C.; Bajaj, K.; Gaetani, E.; Agrati, C.; Grimi, B.; Dulcetti, F.; Ruggeri, A.M.; De Toffol, S.; et al. Fetoplacental mosaicism: Potential implications for false-positive and false-negative noninvasive prenatal screening results. Genet. Med. 2014, 16, 620-624. [CrossRef]

27. Hall, A.L.; Drendel, H.M.; Verbrugge, J.L.; Reese, A.M.; Schumacher, K.L.; Griffith, C.B.; Weaver, D.D.; Abernathy, M.P.; Litton, C.G.; Vance, G.H. Positive cell-free fetal DNA testing for trisomy 13 reveals confined placental mosaicism. Genet. Med. 2013, 15, 729-732. [CrossRef] [PubMed]

28. Grömminger, S.; Yagmur, E.; Erkan, S.; Nagy, S.; Schöck, U.; Bonnet, J.; Smerdka, P.; Ehrich, M.; Wegner, R.D.; Hofmann, W.; et al. Fetal Aneuploidy Detection by Cell-Free DNA Sequencing for Multiple Pregnancies and Quality Issues with Vanishing Twins. J. Clin. Med. 2014, 3, 679-692. [CrossRef]

29. Curnow, K.J.; Wilkins-Haug, L.; Ryan, A.; Kırkızlar, E.; Stosic, M.; Hall, M.P.; Sigurjonsson, S.; Demko, Z.; Rabinowitz, M.; Gross, S.J. Detection of triploid, molar, and vanishing twin pregnancies by a single-nucleotide polymorphism-based noninvasive prenatal test. Am. J. Obstet Gynecol. 2015, 212, e1-e9. [CrossRef]

30. Osborne, C.M.; Hardisty, E.; Devers, P.; Kaiser-Rogers, K.; Hayden, M.A.; Goodnight, W.; Vora, N.L. Discordant noninvasive prenatal testing results in a patient subsequently diagnosed with metastatic disease. Prenat. Diagn. 2013, 33, 609-611. [CrossRef]

31. Yao, H.; Zhang, L.; Zhang, H.; Jiang, F.; Hu, H.; Chen, F.; Jiang, H.; Mu, F.; Zhao, L.; Liang, Z.; et al. Noninvasive prenatal genetic testing for fetal aneuploidy detects maternal trisomy X. Prenat. Diagn. 2012, 32, 1114-1116. [CrossRef]

32. Hartwig, T.S.; Ambye, L.; Sørensen, S.; Jørgensen, F.S. Discordant non-invasive prenatal testing (NIPT) —A systematic review. Prenat. Diagn. 2017, 37, 527-539. [CrossRef] [PubMed]

33. Wang, J.; Wang, Z.W.; Zhou, Q.; Zhang, B.; Yin, T.; Yu, B.; Wang, L. Lower detectability of non-invasive prenatal testing compared to prenatal diagnosis in high-risk pregnant women. Ann. Transl. Med. 2019, 7, 319. [CrossRef]

34. VeriSeq NIPT Solution Package Insert (1000000001856 v07) (illumina.com). Available online: https:/ / support.illumina.com/ content/dam/illumina-support/documents/documentation/chemistry_documentation/dx/veriseq-nipt-solution/veriseqnipt-sample-prep-package-insert-ceivd-1000000001856-07.pdf (accessed on 20 May 2021).

35. Hancock, S.; Ben-Shachar, R.; Adusei, C.; Oyolu, C.B.; Evans, E.A.; Kang, H.P.; Haverty, C.; Muzzey, D. Clinical Experience across the fetal-fraction spectrum of a non-invasive prenatal screening approach with low test-failure rate. Ultrasound Obstet. Gynecol. 2020, 56, 422-430. [CrossRef] [PubMed]

36. Palomaki, G.; Deciu, C.; Kloza, E.M.; Lambert-Messerlian, G.M.; Haddow, J.E.; Neveux, L.M.; Ehrich, M.; van den Boom, D.; Bombard, A.T.; Grody, W.W. DNA sequencing of maternal plasma reliably identifies trisomy 18 and trisomy 13 as well as Down syndrome: An international collaborative study. Genet. Med. 2012, 14, 296-305. [CrossRef] [PubMed] 